\title{
Correlation between Birth Length, Growth, and Development among Children in Rempoah Village Banyumas, Central Java, Indonesia
}

\author{
Sahda Vania Salsabiila, ${ }^{1}$ Qodri Santosa, ${ }^{2}$ Vitasari Indriani, ${ }^{3}$ Kurniawati Arifah, ${ }^{2}$ Joko Setyono, ${ }^{4}$ \\ ${ }^{1}$ Faculty of Medicine Universitas Jenderal Soedirman, Indonesia, ${ }^{2}$ Department of Child Health, \\ Faculty of Medicine Universitas Jenderal Soedirman/Margono Soekarjo Hospital Purwokerto, \\ Indonesia, ${ }^{3}$ Department of Clinical Pathology, Faculty of Medicine Universitas Jenderal \\ Soedirman/Margono Soekarjo Hospital Purwokerto, Indonesia, ${ }^{4}$ Department of Biochemistry \\ Faculty of Medicine Universitas Jenderal Soedirman, Indonesia
}

\section{Abstract}

Background: The first 1,000 days of life are the foundation for growth and development of children in the next period. Birth length may represent growth and development during the intrauterine life. This study aimed to explore the correlation of birth length, growth, and development in children.

Methods: This was analytic observational study with a cross-sectional design. Total sampling was taken, obtaining 368 children aged 6-60 months in several Integrated Service Post (Pos Pelayanan Terpadu, Posyandu), conducted from October to November 2018. Data were gathered from the book of Maternal and Child Health (Kesehatan Ibu dan Anak, KIA), including birth length, body length/height, and nutritional status using weight-for-length/height index. Data were analyzed by Spearman and Eta test.

Results: Birth length was not correlated with nutritional status $(\mathrm{p}=0.108, \mathrm{r}=0.084)$, but had a good correlation with body length/height $(\mathrm{p}=0.027, \mathrm{r}=0.115)$ and development based on the KIA book (F calculated $>$ F table, $\eta=0.245$ ).

Conclusions: There is a correlation between birth length and body length/height as well as a correlation between birth length and development based on the KIA book. It is important for the community and health workers to monitor growth and development of children, by maximizing the use of KIA book.

Keywords: Birth length, children, development, growth

\section{Introduction}

The degree of children's health can reflect the nation's health, since children are the next generation of a country. Optimization of children development is necessary to obtain a good quality of children's future, especially in the first 1,000 days of a child's life as the foundation for the next period. ${ }^{1}$ Based on the Basic Health Research (Riset Kesehatan Dasar) in 2018, about $13.8 \%$ of toddlers are malnourished and $30.8 \%$ of children are stunted in Indonesia. ${ }^{2}$ Approximately 20.2\% of malnourished children in Indonesia have a history of short birth length, which is less than $48 \mathrm{~cm}^{3}$ In 2018, Banyumas was ranked fifth for short birth length children in Central Java. ${ }^{4}$

Regular monitoring is essential to detect any disturbances in early childhood development. Length at birth can describe a child's growth since intrauterine through the size of the birth length. ${ }^{5}$ Previous studies have shown that birth length is associated with child's growth and development. ${ }^{6,7}$ Low birth length can describe growth barriers due to malnutrition during intrauterine periods. ${ }^{8}$ Previous study suggests that birth length is one of the determinants or factors that may delay in child development. ${ }^{9}$ Children with low birth length are at risk of delay or developmental disorders, such as cognitive ability barriers and muscle maturity disorders. ${ }^{5,10}$ 
The study of children's growth and development in Rempoah Village has never been done, therefore, this study aimed to correlate the birth length with children's growth and development in Rempoah Village, Baturaden District, Banyumas, Central Java, Indonesia.

\section{Methods}

The study used an analytic observational design with a cross-sectional approach. Secondary data from the book of Maternal and Child Health (Kesehatan Ibu dan Anak, KIA) were collected and the protocol of the study was approved by the Medical Research Ethics Commission Universitas Jenderal Soedirman Purwokerto (No: 009/KEPK/I/2021).

The sampling technique used in this study was total sampling that recruited children aged 6-60 months at the Integrated Service Post (Pos Pelayanan Terpadu, Posyandu) Bina Kasih I-XI Rempoah Village, during the period from October to November 2018. Children under 2 years old with chronic/congenital diseases or history of prematurity for children or incomplete data were excluded. Measurements in this study were conducted by cadres using standardized and calibrated equipments. The independent variable was length at birth, whereas the dependent variable was children's growth and development, including nutritional status based on weight for length/ height index, body length/height at the time of measurement, and development.

Data were analyzed by Spearman and Eta test. The results were significant if the $p$-value was less than 0.05 (Spearman test) and the F-calculated value was more than the F-table (Eta test).

\section{Results}

A total of 368 out of 568 children were included in this study. The most prevalent age group in this study was the age group of 2536 months $(27.4 \%)$ with more boys $(54.3 \%)$ than girls (45.7\%). Most of the children had normal/good nutritional status $(74.7 \%)$ and age-appropriate development based on the KIA book (93.8\%) (Table 1). The median birth length of the children was $49 \mathrm{~cm}$ (Range 4058 ) and the mean \pm SD was $48.4 \mathrm{~cm} \pm 2.245$.

Correlation analysis using Spearman test showed no statistically significant correlation between birth length and nutritional status

Table 1 Basic Characteristics of Children Aged 6-60 Months from Rempoah Village, Banyumas, Central Java for the Period from October to November 2018

\begin{tabular}{lcc}
\hline \multicolumn{1}{c}{ Characteristics } & Frequency (n) & \% \\
\hline Age (months) & & \\
$6-12$ & 46 & 12.5 \\
$13-24$ & 66 & 17.9 \\
$25-36$ & 101 & 27.4 \\
$37-48$ & 90 & 24.5 \\
$49-60$ & 65 & 17.7 \\
Gender & & \\
Male & 200 & 54.3 \\
Female & 168 & 45.7 \\
Nutritional status & & \\
Severely wasted/wasted & 25 & 6.8 \\
Normal & 275 & 74.7 \\
Risk of over nutrition/over nutrition/obese & 68 & 18.5 \\
Development based on the KIA book & & \\
Age-appropriate & 345 & 93.8 \\
Not appropriate & 23 & 6.3 \\
Birth length (centimeters) & & \\
40-44 & 18 & 4.9 \\
$45-49$ & 244 & 66.3 \\
50-54 & 104 & 28.3 \\
55-59 & 2 & 0.5 \\
\hline
\end{tabular}


Table 2 Correlation between Birth Length, Nutritional Status, Body Length/Height at Measurement, and Development based on the KIA Book

\begin{tabular}{lccccccc}
\hline & \multicolumn{6}{c}{ Birth Length (cm) } \\
\cline { 2 - 7 } & $\mathbf{n}$ & p-value & $\mathbf{r}$ & $\begin{array}{c}\text { Eta } \\
\text { (П) }\end{array}$ & $\begin{array}{c}\text { F } \\
\text { calculated }\end{array}$ & F table \\
\hline Nutritional status & 368 & 0.108 & 0.084 & - & - & - \\
Body length/height at measurement & 368 & 0.027 & 0.115 & - & - & - \\
Development based on the KIA book & - & - & - & 0.245 & 23.36 & 3.86 \\
\hline
\end{tabular}

$(p=0.108)$. However, there was a significant correlation between birth length and body length/height at the time of measurement $(\mathrm{p}=0.027)$ with a positive correlation direction, but very weak correlation $(\mathrm{r}=0.115)$ (Table 2 ). The Eta test indicated that there was a significant correlation ( $\mathrm{F}$ calculated $>\mathrm{F}$ table) between birth length and development based on the KIA book with a positive correlation direction, but the correlation was weak ( $\eta$ $=0.245$ ).

\section{Discussion}

In this study, there is a correlation between birth length and body length/height as well as correlation between birth length and development based on the KIA book, but no significant correlation between birth length and nutritional status.

Similar to previous studies, most of the children aged 25-36 months, more boys with excellent or normal nutritional status. ${ }^{8,9,11}$ Furthermore, most of the children (91.7\%) have normal or age-appropriate development based on the KIA book. ${ }^{12}$ However, this study shows no significant correlation between birth length and nutritional status. Interestingly, previous studies using length/height for age as the nutritional status indicator have shown an association between birth length and nutritional status. ${ }^{7}$ The birth length that is not correlated with nutritional status might be due to the higher level of parents' awareness and knowledge to fulfill children's dietary needs, including providing exclusive breastfeeding and complementary breasfeeding foods (makanan pendamping air susu ibu, MPASI) adequately. The level of parental knowledge about toddlers' adequacy and nutritional needs will affect the type of food their children eat. Optimal and adequate intake of nutrients can reduce the effects of poor intrauterine growth. ${ }^{13,14}$ Malnutrition is a very complex problem since nutritional status is related to many factors such as knowledge of nutrition, family socioeconomic status including poverty, cultural issues in society, community beliefs, food processing techniques, and diet. ${ }^{15}$

There is an association between birth length and body length/height at the time of measurement in a positive direction, but the correlation is very weak. A cohort study of 4,000 children in Brazil ${ }^{16}$ has predicted a significant and positive correlation between birth length and child's length/height in the future with a weak correlation $(\mathrm{r}=0.25)$. Length at birth may represent the intrauterine growth of the child. ${ }^{5}$ Birth length is a critical or essential factor in the linear growth of children aged 0-24 months. Children born with short birth length experienced a slight increase in body length/height compared to other children in their age. ${ }^{17}$ Furthermore, length/height is determined by the interaction between genetic factors, maternal environmental conditions, pregnancy, and nutritional intake. ${ }^{18,19}$ The correlation between birth length and body length/height illustrates that length at birth is related to children's length/height in the future. Early growth of children since intrauterine period needs to be considered properly.

Length at birth correlates with development of children as registered on the KIA book. Short birth length indicates a disruption of child's growth intrauterine, and this might be due to inadequate nutritional intake of the mothers. Therefore, children with short birth lengths are at risk for developmental delays or disruptions.${ }^{6,7}$ Children with short birth lengths are more susceptible to infections which might further disrupt the growth process of the brain, leading to barriers of cognitive abilities that have an impact on children's achievements, exploratory interest, and future thinking abilities. ${ }^{5,10}$ Children with short birth lengths are also at risk of experiencing muscle maturity obstacles, that may cause a decrease in motor skills. Proper rough or smooth motor 
abilities will support children in exploring and interacting with the environments as well as their cognitive, language, socio-emotional development, and vice versa. ${ }^{20}$

There are limitations in this study, such as the measurements that have been performed at one-time by cadres and no direct training to cadres in conducting anthropometric measurements. Future study using cohort study might be useful to observe the children's growth and development patterns. Furthermore, this study did not control for various factors that might influence children's growth and development, such as a history of complications or conditions during pregnancy and childbirth, developmental stimulation, parenting styles, and others. These factors might be of great benefit to be explored in future studies.

To conclude, birth length is correlated with length/height and development based on KIA book, but has no correlation with nutritional status. Regular monitoring of children development at the Posyandu every 3-6 months is imperative. Health workers and policy makers are expected to optimize the use of KIA book and conduct counseling or socialization about the importance of the children's growth and development to the community. Moreover, mother should pay attention to the adequacy of nutritional intake before and during pregnancy.

\section{Acknowledgment}

We would like to thank the Universitas Jenderal Soedirman Purwokerto for providing funding for this research through the BLU Research Program Competency Research Scheme 2018.

\section{References}

1. Beal T, Tumilowicz A, Sutrisna A, Izwardy D, Neufeld. A review of child stunting determinants in Indonesia. Matern Child Nutr. 2018;14(4):e12617.

2. Badan Penelitian dan Pengembangan Kesehatan Kementerian Kesehatan Republik Indonesia. Hasil utama Riset Kesehatan Dasar (Riskesdas) tahun 2018. Jakarta: Badan Penelitian dan Pengembangan Kesehatan Kementerian Kesehatan Republik Indonesia; 2018.

3. Trihono, Atmarita, Tjandrarini DH, Irawati A, Utami NH, Tejayanti F, et al. Pendek (stunting) di Indonesia, masalah, dan solusinya. Jakarta: Lembaga Penerbit Badan Penelitian dan Pengembangan
Kesehatan; 2015.

4. Badan Penelitian dan Pengembangan Kesehatan Kementerian Kesehatan Republik Indonesia. Laporan Provinsi Jawa Tengah Riskesdas 2018. Jakarta: Lembaga Penerbit Badan Penelitian dan Pengembangan Kesehatan Kementerian Kesehatan Republik Indonesia; 2019.

5. Supariasa I, Bakri B, Fajar I. Penilaian status gizi. $2^{\text {nd }}$ Ed. Jakarta: EGC; 2016.

6. Nurmalasari RG, Widyastuti Y, Margono M. Hubungan panjang badan lahir dengan perkembangan anak usia 3-24 bulan di Kabupaten Gunungkidul tahun 2017. Jurnal Kesehatan Ibu dan Anak. 2017;11(1):57-61.

7. Utami NH, Rachmalina R, Irawati A, Sari K, Rosha BC, Amaliah N, et al. Short birth length, low birth weight and maternal short stature are dominant risks of stunting among children aged 0-23 months: evidence from Bogor longitudinal study on child growth and development, Indonesia. Malays J Nutr. 2018;24(1):11-23.

8. Hairunis MN, Salimo $H$, Dewi YLR. Hubungan status gizi dan stimulasi tumbuh kembang dengan perkembangan balita. Sari Pediatri. 2018;20(3):146-51.

9. Kirkegaard $\mathrm{H}$, Möller S, Wu C, Häggström J, Olsen SF, Olsen J, et al. Associations of birth size, infancy, and childhood growth with intelligence quotient at 5 years of age: a Danish cohort study. Am J Clin Nutr. 2020;112(1):96-105.

10. Grantham-Mcgregor SM, Fernald LCH, Kagawa RMC, Walker S. Effects of integrated child development and nutrition interventions on child development and nutritional status. Ann N Y Acad Sci. 2014;1308:11-32.

11. Prastiwi MH. Pertumbuhan dan perkembangan anak usia 3-6 tahun. JIKSH. 2019;8(2):242-9.

12. Dardjito E, Sistiarani C, Nurhayati S. Deteksi pertumbuhan dan perkembangan balita melalui penggunaan buku KIA. Kesmas Indonesia. 2014;6(3):166-75.

13. Rahman MS, Howlader T, Masud MS, Rahman ML. Association of low-birth weight with malnutrition in children under five years in Bangladesh: do mother's education, sosio-economic status, and birth interval matter? PLoS One. 2016;11(6):e0157814.

14. Akombi BJ, AghoKE, Hall JJ, Wali N, Renzaho AMN, Merom D. Stunting, wasting, and underweight in Sub-saharan Africa: a systematic review. Int J Environ Res Public 
Health. 2017;14(8):863-81.

15. Ariati NN, Fetria A, Padmiari IAE, Purnamawati AAP, Sugiani PPS, Suarni NN. Description of nutritional status and the incidence of stunting children in early childhood education programs in BaliIndonesia. Bali Med J. 2018;7(3):723-6.

16. Araújo CLP, Hallal PC, Nader GA, Menezes AMB, Victora CG. Size at birth and height in early adolescence: a prospective birth cohort study. Cad Saúde Publica. 2008;24(4):871-8.

17. Svefors P, Rahman A, Ekström EC, Khan AI, Lindström E, Persson LÅ, et al. Stunted at 10 years: linear growth trajectories and stunting from birth to pre-adolescence in a Rural Bangladeshi Cohort. PloS One. 2016;11(3):e0149700.

18. Jelenkovic A, Yokoyama Y, Sund R, Hur YM, Harris JR, Brandt I, et al. Associations between birth size and later height from infancy through adulthood: an individual based pooled analysis of 28 twin cohorts participating in the CODATwins project. Early Hum Dev. 2018;120:53-60.

19. Latif RVN, Istiqomah N. Determinan stunting pada siswa SD di Kabupaten Pekalongan. Unnes J Public Health. 2017;6(1):68-74.

20. Larson LM, Yousafzai AK. A meta-analysis of nutrition interventions on mental development of children under-two in low- and middle-income countries. Matern Child Nutr. 2017;13(1):e12229. 